\title{
Black Oat (Avena strigosa Schreb.) Ontogenesis and Agronomic Performance in Organic Cropping System and Pannonian Environments
}

\author{
Vladan Ugrenović ${ }^{1}$, Vera Popović ${ }^{2}{ }^{\oplus}$, Milan Ugrinović $^{3}$, Vladimir Filipović ${ }^{4}$, Ksenija Mačkić ${ }^{5, *}$, \\ Nataša Ljubičić ${ }^{6}$, Slobodan Popović ${ }^{7}$ and Željko Lakić ${ }^{8}$
}

check for updates

Citation: Ugrenović, V.; Popović, V.; Ugrinović, M.; Filipović, V.; Mačkić,

K.; Ljubičić, N.; Popović, S.; Lakić, Ž. Black Oat (Avena strigosa Schreb.) Ontogenesis and Agronomic Performance in Organic Cropping System and Pannonian Environments. Agriculture 2021, 11, 55. https:// doi.org/10.3390/agriculture11010055

Received: 8 November 2020 Accepted: 7 January 2021

Published: 12 January 2021

Publisher's Note: MDPI stays neutral with regard to jurisdictional clai$\mathrm{ms}$ in published maps and institutional affiliations.

Copyright: (C) 2021 by the authors. Licensee MDPI, Basel, Switzerland. This article is an open access article distributed under the terms and conditions of the Creative Commons Attribution (CC BY) license (https:// creativecommons.org/licenses/by/ $4.0 /)$.
1 Institute for Soil Science, Teodora Drajzera 7, 11080 Belgrade, Serbia; vladan.ugrenovic@gmail.com

2 Institute of Field and Vegetable Crops, National Institute for the Republic of Serbia, Maxim Gorky 30, 21000 Novi Sad, Serbia; drvvpopovic@gmail.com

3 Institute for Vegetable Crops, Karađorđeva 71, 11420 Smederevska Palanka, Serbia; milan.ugrinovic@gmail.com

4 Institute for Medicinal Plants Research "Dr. Josif Pančić”, Tadeuša Košćuška 1, 11000 Belgrade, Serbia; vladimirmfilipovic@gmail.com

5 Faculty of Agriculture, University of Novi Sad, Obradovica 8, 21000 Novi Sad, Serbia

6 BioSense Institute, University of Novi Sad, Dr. Zorana Đinđića, 21000 Novi Sad, Serbia; ljubicic.natasa@gmail.com

7 Faculty of Economy, University of Novi Sad, 21000 Novi Sad, Serbia; slobodan.popovic49@gmail.com

8 Faculty of Agriculture, University of Banja Luka, 78000 Banja Luka, Bosnia and Herzegovina; lakic.kiko@gmail.com

* Correspondence: ksenija@polj.uns.ac.rs

\begin{abstract}
This study examined the influence of agroecological conditions on the ontogenesis and production yield traits of black oat (Avena strigosa Schreb.). Understanding the agronomic and phenological properties related to productive properties of black oats can enable more successful introduction into new areas of oat cultivation. Field microexperiments were performed during the three consecutive years (2017-2019) on the two localities in South Banat, in Serbia, which differed in soil type: carbonate chernozem and humogley, respectively. The results showed that all investigated traits of oat in the chernozem soil type were higher when compared with measured traits obtained from the humogley soil type. The average value of yields of aboveground biomass, yield and protein content were significantly higher in relation to the humogley, by $13 \%, 17 \%$ and $11 \%$, respectively for all three seasons. Observed by years, all productivity parameters differed significantly, which confirmed that the productivity of the cultivated plants was strongly influenced by different agroecological, soil and climatic conditions in Pannonian environments. The aboveground biomass and grain yield obtained from the humogley soil type indicate that this species can be successfully grown and utilized in production as a cover or fodder crop even in less favorable soil conditions.
\end{abstract}

Keywords: black oats; locality; ontogenesis; productivity parameters; soil

\section{Introduction}

The black oat (Avena strigosa Schreb.) belongs to the diploid subgroup of cultivated annual species of the genus Avena, with an open and loose panicle. It differs from other cultivated species of this genus by thin and tall stem and outer glumes that end in two thin awn looking outgrowths [1]. This plant species has moderate requirements for climatic and soil conditions. It tolerates drought well [2], but is less resistant to low temperatures because it freezes in winter at temperatures below $-7^{\circ} \mathrm{C}$ [3]. This limits cultivation to a certain extent, so it is more often grown as a spring crop. The black oat tolerates lower soil fertility levels well. It is tolerant to acidic soils ( $\mathrm{pH} 4.5$ to 7.3), and is best suited to sandy and loamy soils [2]. 
The black oats' center of origin is considered to be the Iberian Peninsula, from where it spread to Western and Central Europe and occupied a number of ecological niches in the area all the way to the plains of Afghanistan. At first, this species was originally a weed in other cereals, but since the Bronze Age it has been cultivated and used in human nutrition or as animal feed. Over time, cultivation and use declined, so that at the end of the twentieth century it was on the verge of extinction in Europe [4]. The reason for this was the introduction of more productive cultivated forms of $A$. sativa L. [5-7]. In recent years in Europe, efforts have been made to conserve the genetic resources of the black oat as well as revive its production [8]. The black oat is considered an excellent feed for cattle due to its high nutritional value and good digestibility [9]. Due to its biological properties, such as the ability to remediate soil via the phytoextraction of heavy metals, and allelopathic and nematocidal effects, it finds application in sustainable agricultural production systems as a cover crop $[10,11]$. Therefore, for the needs of the EU, in the area of Vojvodina province, the production of black oat seeds has been organized since 2013 (Scheme 1), which also represents its introduction into Serbia [12].

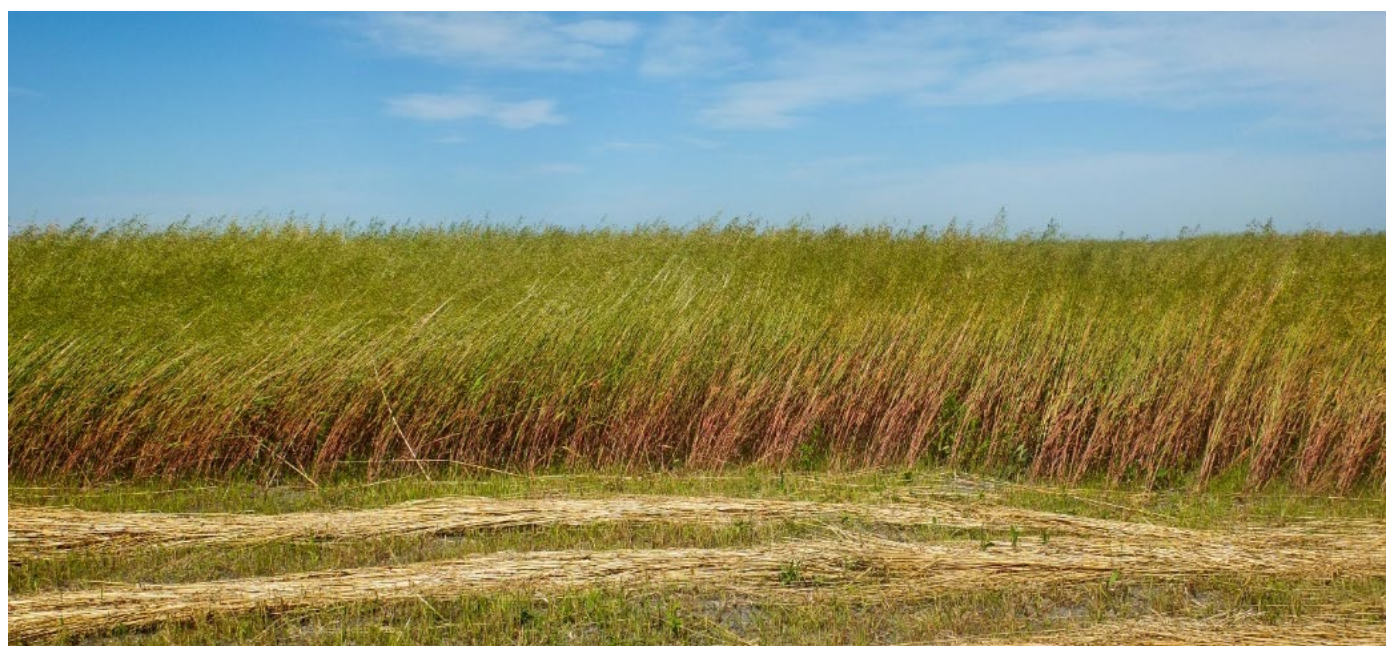

Scheme 1. Black oat seed production near Alibunar city, Serbia (Photo: Ugrenović, 2018).

Beside the fact that oat, like many other cereals, the black oat is highly adaptable, only cultivars with modest input demands are suitable for growing in different stress environments [13]. The less productive soils could significantly decrease the production. Due to differences in the structure of the pedological profile, the processes of transformation and migration of mineral and organic matter, as well as physicochemical characteristics, the productivity and quality of plants are different in different types of soil [14]. However, with knowledge of the genetic resources, the needs of plants and plant response, as well as the agroecological conditions of the specific region, it is possible to optimize plant production and the rational use of production inputs.

Therefore, the main purpose of this study was to evaluate the performance of commercial black oat varieties in different localities, different soil type and different years of study. In that sense, the goal of the conducted research was to study the ontogenesis and productive characteristics of this new plant species in organic production systems in different agroecological conditions of Pannonian environments. The best management practices identified in this preliminary study can then be verified and extrapolated to other locations with similar biophysical, climatic, and socioeconomic characteristics.

\section{Materials and Methods}

\subsection{Field Experiments}

The field microtrials were performed at two locations with different soil types, near

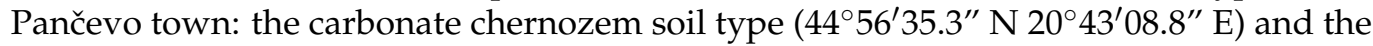


humogley soil type $\left(44^{\circ} 52^{\prime} 20.7^{\prime \prime} \mathrm{N} 20^{\circ} 42^{\prime} 04.0^{\prime \prime} \mathrm{E}\right)$ during the three consecutive growing season $(2017,2018$ and 2019). The previously grown crop was soybean, in all three years of research. Unhulled black oat (A. strigosa Schreb) seeds, the specific variety being "Pratex" were sown in early March, with a seeding rate of 500 germinated seeds per $\mathrm{m}^{2}$. The area of the basic plot was $5 \mathrm{~m}^{2}$, i.e., $4 \mathrm{~m}$ long, $1.25 \mathrm{~m}$ wide, with a spacing of $12.5 \mathrm{~cm}$ between the rows, consisting of ten rows each. The trials were set up according to a two-factorial design with four replications. Black oat plants were grown in accordance with organic production methods i.e., without any application of fertilizers to enhance growth, and without pesticides to manage weeds, diseases and pests.

During the vegetation season, the following growth phases were monitored according to the Biologische Bundesanstalt and Chemical industry-BBCH scale [15] in the following grow stages: the first leaf through coleoptile germination $(\mathrm{BBCH} 10)$, the beginning of tillering (BBCH 21), the beginning of stem elongation (BBCH 30)the end of heading (BBCH 59), soft dough (BBCH 85) and full ripeness (BBCH 89). At the stage of full maturity (BBCH 89), plant height was measured $(\mathrm{cm})$ while plants in one square meter were harvested from the experimental plots individually to record aboveground biomass $\left(\mathrm{t} \mathrm{ha}^{-1}\right)$. After threshing the biomass of the plants, the total yield of husked grains in $\mathrm{tha}^{-1}$ was determined, and after their hulling, the yield of hulled grain was determined in $\mathrm{t} \mathrm{ha}^{-1}$. By comparing the yield of hulled grain with the yield of the aboveground biomass, the harvest index in \% was obtained [16], and the share of chaff and husk in the total mass of chaff grains was also determined, which is expressed by the hull index in \% [17]. The total nitrogen (N) and carbon (C) in grain were measured using a CNS Elemental Analyzer (vario El III) while total protein content (\%) was calculated using the equation of Jones factor [18].

\subsection{Meteorological Conditions during Vegetation Periods}

Data from the Meteorological Institute of Serbia were used for for the Pancevo site for the analysis of the amount and distribution of precipitation and thermal conditions during the three consecutive vegetation periods of black oats (Figure 1).

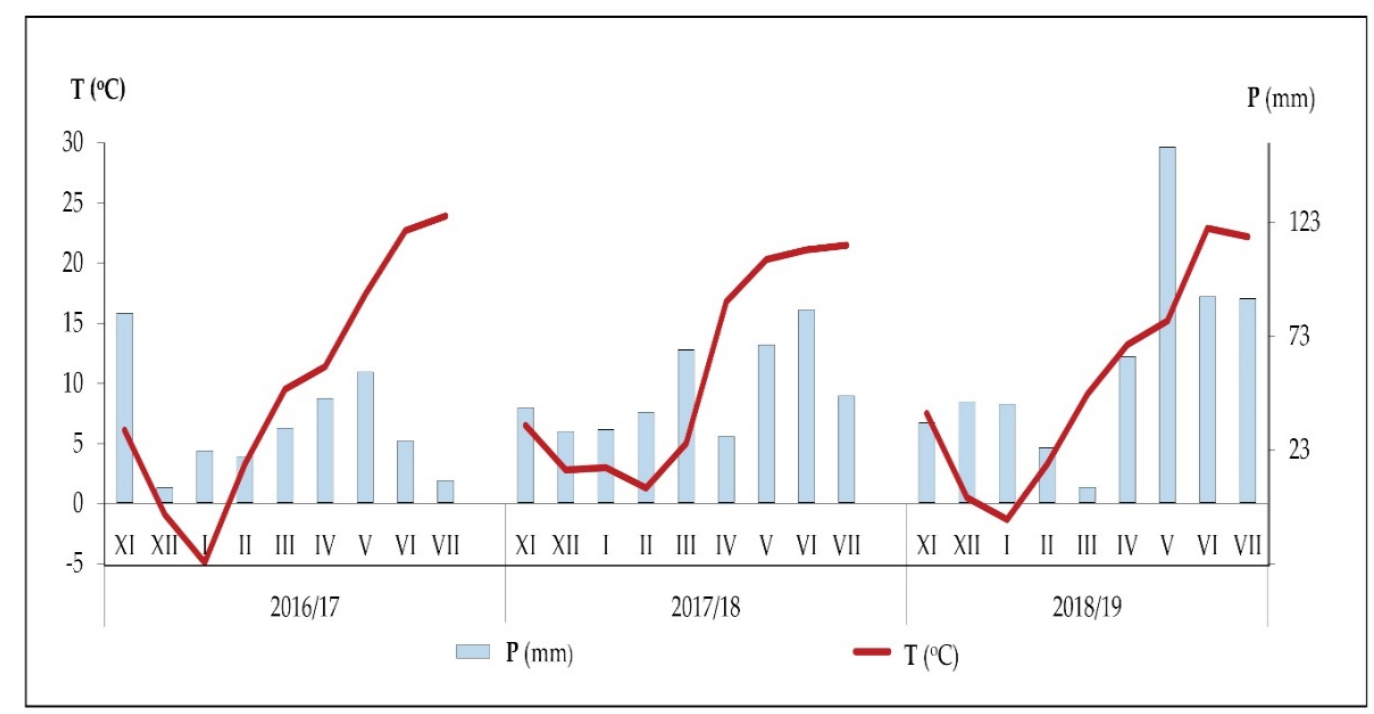

Figure 1. Precipitation $(\mathrm{mm})$ and average air temperature $\left({ }^{\circ} \mathrm{C}\right)$ during the microtrials, Pancevo, Republic of Serbia, 2016-2019, where T: presents temperature $\left({ }^{\circ} \mathrm{C}\right)$; P: precipitation $(\mathrm{mm})$.

The heat sum during the vegetation period of black oat was approximately the same in the first $\left(2597.8^{\circ} \mathrm{C}\right)$ and second year of the study $\left(2587.8^{\circ} \mathrm{C}\right)$, and lower in the third $\left(2524.5^{\circ} \mathrm{C}\right)$. The analysis of average monthly temperatures indicates that March 2018 was significantly colder $\left(5.0^{\circ} \mathrm{C}\right)$ compared to $2017\left(9.5^{\circ} \mathrm{C}\right)$ and $2019\left(9.1^{\circ} \mathrm{C}\right)$. For that reason, in 2018, plant emergence and the beginning of the vegetation period were slowed down. It was also, in the same year, extremely warm: April $\left(16.8^{\circ} \mathrm{C}\right)$ and May $\left(20.3^{\circ} \mathrm{C}\right)$, which 
adversely affected the growth and development of the plants. The monthly water regime in the winter period in all years of research was suitable for plant growth. The average amount of precipitation during the black oat vegetation period was highest in the third year of research $(406.6 \mathrm{~mm})$, lower in the second $(296.3 \mathrm{~mm})$, and lowest in the first $(172.1 \mathrm{~mm})$. The monthly water regime in the third year was favorable, with enough water in the periods of the greatest consumption, while in the first year in June $(27 \mathrm{~mm})$, and in the second in April $(29 \mathrm{~mm}$ ) there was a shortage (Figure 1).

\subsection{Soil Properties}

The sites of the experiments in three vegetation seasons of the chernozem soil type (latitude $\left.44^{\circ} 56^{\prime} 35.3^{\prime \prime} \mathrm{N} 20^{\circ} 43^{\prime} 08.8^{\prime \prime} \mathrm{E}\right)$ and the humogley soil type $\left(44^{\circ} 52^{\prime} 20.7^{\prime \prime} \mathrm{N} 20^{\circ} 42^{\prime} 04.0^{\prime \prime} \mathrm{E}\right)$ were set up in Pannonian Plain, Banat region, near Pančevo town.

The texture of chernozem soil is a predominantly loamy and crumbly structure with stable aggregates with favorable air and thermal regimes for plant production [19]. chernozem belongs to automorphic soils with class A-C. It is the most suitable soil for agricultural production, because it is characterized by a deep profile and suitable physical and chemical properties. This soil type covers $10589.6 \mathrm{~km}^{2}$, or $12 \%$ of the territory of Serbia.

Humogley belongs to hydromorphic soils with A-G profile. It is formed in the field of rivers, at a greater distance from the riverbed, where the smallest clay particles accumulate. It is characterized by shallow groundwater that affects anaerobic conditions and the formation of a humus horizon of the hydromorphic type. It belongs to the potentially fertile soil group, but intensive use is possible only with cultivation and drainage $[19,20]$. It occuping $4468.90 \mathrm{~km}^{2}$, or $5.1 \%$ of the territory of Serbia.

The results of the chemical analysis of the soil samples are presented in Table 1. The soil was analyzed using chemical methods: soil $\mathrm{pH}$ was determined in a 1:2.5 soil $1 \mathrm{M}$ $\mathrm{KCl}$ suspension after a half-hour equilibration period; hydrolytic acidity by Ca acetate extraction using Kappen's method; the sum of exchangeable basic cations by Kappen's method; humus content by Kotzmann's method; total nitrogen by Kjeldahl, and available $\mathrm{P}_{2} \mathrm{O}_{5}$ and $\mathrm{K}_{2} \mathrm{O}$ levels by the Egner-Riehm Al method.

Table 1. The agrochemical properties of soil ${ }^{1}$.

\begin{tabular}{ccccccccc}
\hline \multirow{2}{*}{ Location/Soil Type } & \multicolumn{2}{c}{$\mathrm{pH}$} & $\mathrm{CaCO}_{3}$ & Humus & Total N & \multicolumn{2}{c}{$\begin{array}{c}\text { Available, } \\
\mathbf{m g} / \mathbf{1 0 0} \mathbf{g}\end{array}$} \\
\cline { 2 - 9 } & $\mathbf{n K C l}$ & $\mathbf{H}_{\mathbf{2}} \mathbf{O}$ & $\mathbf{\%}$ & $\mathbf{\%}$ & $\mathbf{\%}$ & $\mathbf{P}_{\mathbf{2}} \mathbf{O}_{\mathbf{5}}$ & $\mathbf{K}_{\mathbf{2}} \mathbf{O}$ \\
\hline Pancevo-chernozem & 7.4 & 8.0 & 12.1 & 3.43 & 0.23 & 19.7 & 16.4 \\
\hline Pancevo-humogley & 5.4 & 6.4 & 1.3 & 2.31 & 0.18 & 3.6 & 36.2 \\
\hline
\end{tabular}

${ }^{1}$ Agrochemical analyses of soil samples from the experimental fields were performed in the laboratory of the Institute Tamis, in late 2017, Pancevo, Serbia.

According to the results of agrochemical analysis, the soil is slightly alkaline ( $\mathrm{pH}$ in $\mathrm{H}_{2} \mathrm{O} 7.4$ and $\mathrm{pH}$ in $\mathrm{KCl} 8.0$ ), very carbonate $(12.1 \%)$, medium in humus $(3.43 \%)$, wellprovided with $\mathrm{N}(0.23 \%)$, and rich in available phosphorus and potassium (19.7 and $16.4 \mathrm{mg} 100^{-1} \mathrm{~g}$ of soil), (Table 1 ).

In humogley the soil is acidic ( $\mathrm{pH}$ in $\left.\mathrm{H}_{2} \mathrm{O} 5.4\right)$, weakly carbonate $(1.3 \%)$, poor in humus $(2.31 \%)$, medium in total $\mathrm{N}(0.18 \%)$, poor in available phosphorus $\left(3.6 \mathrm{mg} 100^{-1} \mathrm{~g}\right.$ of soil) and highly provided with readily available potassium $\left(36.2 \mathrm{mg} 100^{-1} \mathrm{~g}\right.$ of soil).

\subsection{Statistical Analysis}

The experimental data obtained were analyzed using descriptive and analytical statistics using the statistical package STATISTICA 12 for Windows. Significance testing of the differences between the calculated mean values of the examined factors (soil type/location and years) was performed using a two-factor model of variance analysis. All significance ratings were based on the F-test and LSD-test for significance level of $0.05 \%$ and $0.01 \%$. The 
relative dependence was determined by the method of correlation analysis (Pearson's correlation coefficients), and the obtained coefficients were tested by $t$-test at the significance level of $0.05 \%$ and $0.01 \%$.

\section{Results}

\subsection{Ontogenesis/Individual Development}

In this study, the black oat growth stages are represented by external or phenotypic changes in the plants (Table 2). In all years of research, the plants underwent phenophases at the same time $\mathrm{n}$ both chernozem and humogley soil types, while climatic conditions, which varied by year, influenced the dynamics of their occurrence. In all years of research, black oat plants emerged simultaneously in chernozem and humogley (Table 2).

Table 2. Black oat growing stages $(\mathrm{BBCH})$ and its dates of occurrence during the experiment.

\begin{tabular}{|c|c|c|c|c|c|c|c|c|c|}
\hline \multirow{4}{*}{$\begin{array}{c}\text { Year } \\
\begin{array}{c}\text { Growth } \\
\text { Stages }\end{array} \\
\text { BBCH } 10^{*}\end{array}$} & \multicolumn{3}{|c|}{2017} & \multicolumn{3}{|c|}{2018} & \multicolumn{3}{|c|}{2019} \\
\hline & \multirow{2}{*}{$\mathbf{A D} * *$} & PD & DAS & \multirow{2}{*}{ AD } & PD & DAS & \multirow{2}{*}{ AD } & PD & DAS \\
\hline & & \multicolumn{2}{|c|}{ (Days) } & & \multicolumn{2}{|c|}{ (Days) } & & \multicolumn{2}{|c|}{ (Days) } \\
\hline & 05.03-14.03. & 9 & 9 & 05.03-30.03. & 25 & 25 & 05.03-15.03. & 10 & 10 \\
\hline ВBCH 30 & $28.03-20.04$. & 23 & 46 & $14.04-27.04$ & 13 & 53 & $30.03-18.04$. & 19 & 45 \\
\hline BBCH 59 & $20.04-25.05$. & 35 & 81 & $27.04-23.05$. & 26 & 79 & $18.04-25.05$. & 37 & 81 \\
\hline ВBCH 85 & $25.05-26.06$. & 32 & 113 & $23.05-27.06$ & 35 & 114 & $25.05-04.07$. & 40 & 121 \\
\hline ВBCH 89 & $26.06-29.06$. & 3 & 118 & $27.06-02.07$. & 5 & 119 & 04.07-09.07. & 5 & 126 \\
\hline \multicolumn{2}{|c|}{ *** Vegetation period (total) } & \multicolumn{2}{|c|}{107} & \multicolumn{3}{|c|}{95} & \multicolumn{3}{|c|}{116} \\
\hline
\end{tabular}

* 10-The first leaf through coleoptile emergence; 21 - The beginning of tillering; 30-The beginning of stem elongation; 59-The end of heading; 85-The soft dough ripening; 89-The fully ripe harvest; ${ }^{* *} \mathrm{AD}$-appearing date; PD—stage duration; DAS—days after sowing; ${ }^{* * *}$ The number of days from germination to full maturity.

The number of days from sowing to germination was approximately the same in the first and third year ( 9 and 10 days, respectively), and significantly longer in the second, with the coldest month of March ( 25 days). In the first and third year, this phase occurred at approximately the same time (March, 28 and 30 days, respectively). The later tillering in the second year (April 14), followed by a sharp rise in air temperature, shortened this phase, so the plants quickly went into intensive growth and the side shoots remained undeveloped.

The period from the beginning of stem elongation to the end of heading lasted the longest in the third year (37 days), was a little shorter in the first year (35 days) and was the shortest in the second year ( 26 days). The period from heading to the soft dough ripening stage was the longest in the third year ( 40 days); in the second it was shorter by 5 and in the first by 8 days. The duration of the fruit development stage, precisely grain filling is significantly influenced by environmental factors, primarily by high temperatures which shorten this period [21]. Full ripening occurred the earliest and very abruptly in the first year, which had the warmest and driest June (June 29), in the second 3 days later, and in the third 10 days later.

The average length of the black oats' vegetation period on chernozem and humogley in all three years of research was 105 days, Figure 2. The longest in the third year, 116 days, shorter in the first, 107 days, and the shortest in the second, 95 days. In our study, black oat showed similar ontogenesis pattern compared to other cereal grains in the agroecological conditions of the South Banat region. 


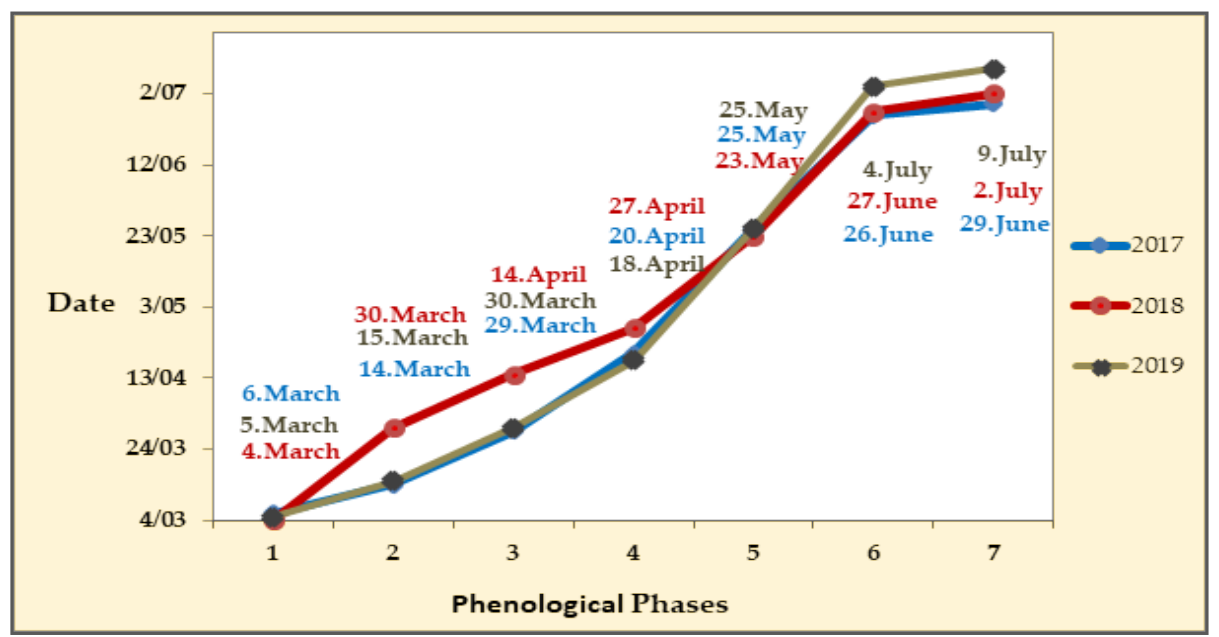

Figure 2. The dates of the beginning of black oat phenophases in chernozem and humogley soil types (2017-2019). Phenophases: 1—sowing (BBCH 00); 2-frst leaf through coleoptile germination (BBCH 10); 3-the beginning of tillering (BBCH 21); 4-the beginning of stem elongation (BBCH 30); 5-the end of heading (BBCH 59); 6-soft dough (BBCH 85); 7-fully ripe (BBCH 89).

\subsection{Productivity Parameters}

\subsubsection{Plant Height}

The presented results revealed that the mean values of the plant height in both types of soil for all three seasons of research varied from $104.88 \mathrm{~cm}$ to $112.25 \mathrm{~cm}$, Table 3 .

Table 3. The average value of tested morpho-productive parameters in the chernozem and humogley soil types during 2017-2019.

\begin{tabular}{|c|c|c|c|c|c|c|c|c|c|c|c|c|c|}
\hline $\begin{array}{l}\text { Soil } \\
\text { Type * }\end{array}$ & Year & \multicolumn{2}{|c|}{ PH (cm) } & \multicolumn{2}{|c|}{ BY $\left(t_{\text {ha }}{ }^{-1}\right)$} & \multicolumn{2}{|c|}{ GY $\left(t h^{-1}\right)$} & \multicolumn{2}{|c|}{ HI (\%) } & \multicolumn{2}{|c|}{ HUI (\%) } & \multicolumn{2}{|c|}{ PC (\%) } \\
\hline \multirow{3}{*}{ L1-Ch } & 2017 & \multicolumn{2}{|c|}{$107.75 \pm 3.30$} & \multicolumn{2}{|c|}{$12.77 \pm 0.06$} & \multicolumn{2}{|c|}{$1.41 \pm 0.03$} & \multicolumn{2}{|c|}{$10.99 \pm 0.23$} & \multicolumn{2}{|c|}{$22.06 \pm 0.20$} & \multicolumn{2}{|c|}{$18.39 \pm 0.44$} \\
\hline & 2018 & \multicolumn{2}{|c|}{$104.00 \pm 3.56$} & \multicolumn{2}{|c|}{$12.18 \pm 0.03$} & \multicolumn{2}{|c|}{$1.19 \pm 0.03$} & \multicolumn{2}{|c|}{$9.77 \pm 0.23$} & \multicolumn{2}{|c|}{$21.61 \pm 0.08$} & \multicolumn{2}{|c|}{$16.84 \pm 0.38$} \\
\hline & 2019 & \multicolumn{2}{|c|}{$112.25 \pm 2.75$} & \multicolumn{2}{|c|}{$14.11 \pm 0.11$} & \multicolumn{2}{|c|}{$2.08 \pm 0.02$} & \multicolumn{2}{|c|}{$14.78 \pm 0.08$} & \multicolumn{2}{|c|}{$21.35 \pm 0.44$} & \multicolumn{2}{|c|}{$17.89 \pm 0.84$} \\
\hline \multicolumn{2}{|l|}{ Average } & \multicolumn{2}{|c|}{$108.00 \pm 4.57$} & \multicolumn{2}{|c|}{$13.02 \pm 0.85$} & \multicolumn{2}{|c|}{$1.56 \pm 0.38$} & \multicolumn{2}{|c|}{$11.85 \pm 2.23$} & \multicolumn{2}{|c|}{$21.67 \pm 0.40$} & \multicolumn{2}{|c|}{$17.71 \pm 0.86$} \\
\hline \multirow{3}{*}{ L2-Hu } & 2017 & 106.0 & \pm 2.16 & 10.67 & $=0.09$ & 1.09 & $=0.02$ & 10.22 & \pm 0.14 & 22.09 & \pm 0.14 & 16.12 & $=0.16$ \\
\hline & 2018 & 101.7 & \pm 2.75 & 10.25 & 0.27 & 0.99 & 0.05 & 9.68 & 0.23 & 21,97 & 0.27 & 15.17 & $=0.20$ \\
\hline & 2019 & 111.7 & \pm 2.50 & 12.94 & 0.04 & 1.81 & $=0.04$ & 13.99 & \pm 0.07 & 21.66 & 0.17 & 15.95 & $=0.28$ \\
\hline Average & & 106.5 & \pm 4.83 & 11.29 & $=1.24$ & 1.29 & $=0.38$ & 11.29 & \pm 2.02 & 20.90 & \pm 0.26 & 16.73 & $=1.21$ \\
\hline $\begin{array}{c}\text { Average } \\
2017\end{array}$ & & 106.8 & $=4.57$ & 11.72 & 1.05 & 1.24 & $=0.17$ & 10.61 & \pm 0.46 & 22.07 & \pm 0.16 & 17.26 & $=1.25$ \\
\hline $\begin{array}{c}\text { Average } \\
2018\end{array}$ & & 102.8 & $=3.18$ & 11.22 & 1.04 & 1.11 & 0.04 & 9.73 & $=0.24$ & 21.79 & 0.27 & 16.01 & $=0.94$ \\
\hline $\begin{array}{c}\text { Average } \\
2019\end{array}$ & & 112.0 & 2.45 & 13.53 & 0.63 & 1.9 & 0.15 & 14.3 & 0.48 & 21.5 & 0.35 & 16.9 & $=1.19$ \\
\hline $\begin{array}{l}\text { Average L1 } \\
+ \text { L2 }\end{array}$ & & 107.2 & 4.66 & 12.16 & 1.35 & 1.43 & 0.41 & 11.57 & \pm 2.10 & 21.78 & $=0.35$ & 16.72 & $=1.21$ \\
\hline Parameter & & & $\mathrm{cm})$ & BY ( & $\left.a^{-1}\right)$ & GY & $\left.\mathrm{ha}^{-1}\right)$ & & $(\%)$ & $\mathrm{HU}$ & $(\%)$ & & $\%)$ \\
\hline SD & & 0.5 & 0.1 & 0.5 & 0.1 & 0.5 & 0.1 & 0.5 & 0.1 & 0.5 & 0.1 & 0.5 & 0.1 \\
\hline $\mathrm{L}$ & & 2.492 & 3.039 & 0.113 & 0.138 & 0.032 & 0.244 & 0.200 & 0.244 & 0.259 & 0.356 & 0.316 & 0.525 \\
\hline Year & & 3.051 & 3.722 & 0.139 & 0.169 & 0.039 & 0.048 & 0.245 & 0.299 & 0.212 & 0.291 & 0.387 & 0.643 \\
\hline $\mathrm{L} \times \mathrm{Y}$ & & 4.315 & 5.264 & 0.196 & 0.239 & 0.055 & 0.068 & 0.346 & 0.423 & 0.367 & 0.503 & 0.547 & 0.909 \\
\hline
\end{tabular}

${ }^{*}$ L1-Ch: the first locality with chernozem type of soil; L2-Hu: the second locality with humogley soil types during three growing season of 2017, 2018 and 2019; PH: plant height; BY: biomass yield, GY: grain yield, HI: harvest index; HUI: hull index; PC: protein content.

In the first locality, in chernozem soil (L1-Ch) and from $101.75 \mathrm{~cm}$ to $111.75 \mathrm{~cm}$ for the second locality, in humogley soil (L2-Hu), (Table 3). 
Soil type did not have a statistically significant effect on this parameter, but in chernozem soil $(108 \mathrm{~cm})$ the plants were $1.65 \%$ taller than in humogley (Table 3). Beside of influence of different soil conditions, the effect of weather conditions during three different seasons was also shown as a significant source of plant height variation. The results showed that the year factor significantly affected this trait. In 2019 the average value of plant height $(112.00 \mathrm{~cm})$ was statistically significantly higher compared to both the $2018(102.88 \mathrm{~cm})$ and $2017(106.88 \mathrm{~cm}$ ) averages (Tables 3 and 4).

Table 4. Analysis of variance for the tested parameters.

\begin{tabular}{|c|c|c|c|c|c|}
\hline Effect & SS & DF & MS & $\mathbf{F}$ & $p$ \\
\hline \multicolumn{6}{|c|}{ Plant height } \\
\hline Intercept & 276061.50 & 1 & 276061.50 & 33349.72 & 0.00000 \\
\hline Year & 334.80 & 2 & 167.40 & $20.22 *$ & 0.00002 \\
\hline Soil type & 13.50 & 1 & 13.51 & 1.63 & 0.21781 \\
\hline $\mathrm{Y} \times \mathrm{L}$ & 3.30 & 2 & 1.60 & 0.20 & 0.82349 \\
\hline Error & 149.00 & 18 & 8.30 & & \\
\hline \multicolumn{6}{|c|}{ Biomass yield } \\
\hline Intercept & 3546.29 & 1 & 3546.29 & 207581.20 & 0.00000 \\
\hline Year & 23.632 & 2 & 11.82 & $691.70 *$ & 0.00000 \\
\hline Soil type & 17.98 & 1 & 17.99 & $1052.91 *$ & 0.00000 \\
\hline $\mathrm{Y} \times \mathrm{L}$ & 0.96 & 2 & 0.48 & $28.21 *$ & 0.00000 \\
\hline Error & 0.31 & 18 & 0.02 & & \\
\hline \multicolumn{6}{|c|}{ Grain yield } \\
\hline Intercept & 49.03 & 1 & 49.03 & 35969.23 & 0.00000 \\
\hline Year & 3.33 & 2 & 1.67 & $1222.26^{*}$ & 0.00000 \\
\hline Soil type & 0.41 & 1 & 0.41 & $303.78 *$ & 0.00000 \\
\hline $\mathrm{Y} \times \mathrm{L}$ & 0.01 & 2 & 0.01 & $5.05^{*}$ & 0.01814 \\
\hline Error & 0.02 & 18 & 0.0014 & & \\
\hline \multicolumn{6}{|c|}{ Harvest index } \\
\hline Intercept & 3214.91 & 1 & 3214.91 & 60260.03 & 0.00000 \\
\hline Year & 98.06 & 2 & 49.03 & $918.97 * *$ & 0.00172 \\
\hline Soil type & 1.87 & 1 & 1.87 & $35.13 *$ & 0.00001 \\
\hline $\mathrm{Y} \times \mathrm{L}$ & 0.62 & 2 & 0.310 & $5.82 *$ & 0.01125 \\
\hline Error & 0.96 & 18 & 0.05 & & \\
\hline \multicolumn{6}{|c|}{ Hull index } \\
\hline Intercept & 11394.80 & 1 & 11394.80 & 187026.80 & 0.00000 \\
\hline Year & 1.29 & 2 & 0.65 & $9.60 *$ & 0.00190 \\
\hline Soil type & 0.32 & 1 & 0.32 & $5.33 *$ & 0.03313 \\
\hline $\mathrm{Y} \times \mathrm{L}$ & 0.13 & 2 & 0,06 & $1.10^{*}$ & 0.36870 \\
\hline Error & 1.10 & 18 & 0.06 & & \\
\hline \multicolumn{6}{|c|}{ Protein content } \\
\hline Intercept & 6716.09 & 1 & 6716.09 & 33864.14 & 0.00000 \\
\hline Year & 6.75 & 2 & 3.38 & $17.02 * *$ & 0.00007 \\
\hline Soil type & 23.05 & 1 & 23.05 & $116.24^{* *}$ & 0.00000 \\
\hline $\mathrm{Y} \times \mathrm{L}$ & 0.37 & 2 & 0.18 & $0.93 * *$ & 0.41344 \\
\hline Error & 3.57 & 18 & 0.19 & & \\
\hline
\end{tabular}

* Significant at $0.05 ;{ }^{* *}$ Significant at 0.01 ; SS: the sum of squares; DF: the degrees of freedom; MS: the mean sum of squares; F: F-statistics; $p$ : $p$-value. 


\subsubsection{Aboveground Plant Biomass (Biomass Yield)}

Soil type, year, and soil type $\mathrm{x}$ year interaction significantly affected this productivity parameter (Table 3). The average yield of aboveground biomass on both soil types and in all three years of our research was $12.16 \mathrm{t} \mathrm{ha}^{-1}$. In chernozem soil, a significantly higher average yield of aboveground biomass $\left(13.02 \mathrm{tha}^{-1}\right)$ was achieved compared to humogley $\left(11.29 \mathrm{t} \mathrm{ha}^{-1}\right)$. The year also had a significant impact and therefore the yield of aboveground biomass in 2019 (13.53 $\left.\mathrm{tha}^{-1}\right)$ was statistically significantly higher compared to $2018\left(11.22 \mathrm{t} \mathrm{ha}^{-1}\right)$ and $2017\left(11.72 \mathrm{t} \mathrm{ha}^{-1}\right)$. Better meteorological conditions in that period also showed a good impact on aboveground plant biomass production.

\subsubsection{Harvest Index}

Locality or soil type, year and soil type $\mathrm{x}$ year interaction significantly influenced the calculated value of this productivity parameter. On average, in both types of soil in all three years of research, the harvest index was $11.5 \%$ (Table 3).

In chernozem, a significantly higher harvest index was achieved $(11.85 \%)$ compared to humogley $(11.29 \%)$. Looking at each year separately, it was observed that the harvest index in $2019(14.38 \%)$ was significantly higher $(p<0.01)$ compared to the $2018(9.72 \%)$ and $2017(11.29 \%)$ seasons.

\subsubsection{Grain Yield}

This trait shows the yield after husking the grain using special processing devices. The soil type, year and soil type $\mathrm{x}$ year interaction, significantly influenced this parameter (Table 2).

The average grain yield in both soil types and in all three years of research was $1.43 \mathrm{tha}^{-1}$ and varied from $1.29 \mathrm{t} \mathrm{ha}^{-1}$ in humogley, to $1.56 \mathrm{t} \mathrm{ha}^{-1}$ in chernozem. These variations were statistically significant; looking at the years, in 2019 the yield $\left(1.95 \mathrm{t} \mathrm{ha}^{-1}\right)$ was statistically significantly higher compared to $2018\left(1.11 \mathrm{t} \mathrm{ha}^{-1}\right)$ and $2017\left(1.24 \mathrm{t} \mathrm{ha}^{-1}\right)$, (Tables 3 and 4).

Aside from the soil type, better meteorological conditions in that period also had a significant impact on grain yield production.

\subsubsection{Hull Index}

The average value of this parameter on both types of soil and in all three years of research was $21.78 \%$, and it varied from $21.67 \%$ in chernozem, to $21.90 \%$ in humogley (Tables 3 and 4). These variations were statistically significant, and the year also had an impact, so that in 2017 the hull index $(22.07 \%)$ was significantly higher compared to 2019 $(21.51 \%)$ and $2018\left(21.79 \mathrm{t} \mathrm{ha}^{-1}\right)$, (Tables 3 and 4$)$.

\subsubsection{Protein Content}

The locality (soil type), year and soil type $x$ year interaction significantly influenced the calculated value of protein content. On average, in both types of soil and in three years of research, the protein content was $16.73 \%$ (Table 3).

In chernozem, a significantly higher protein content was achieved (17.71\%) compared to humogley $(15.75 \%)$ (Table 3). Looking at each of the years, the protein content in 2017 was significantly higher (17.26\%) compared to 2018 (16.01\%) and $2019(16.92 \%)$.

Based on the analysis of variance, highly significant differences of grain yield with regard to the soil type were noted $\left(\mathrm{Fexp}=303.78^{* *}\right)$. Significant differences are also noted for biomass yield $\left(\mathrm{Fexp}=1052.91^{*}\right)$, protein content $\left(\mathrm{Fexp}=116.24^{*}\right)$ and harvest index $\left(\right.$ Fexp $\left.=35.13^{*}\right)$, with regard to the soil type (Table 4$)$.

\subsection{Correlation of Tested Parameters}

The above ground biomass was in strong positive correlation with grain yield $(\mathrm{r}=0.92 * *)$, in positive correlation with the harvest index $\left(r=0.82{ }^{*}\right)$, plant height $\left(r=0.72{ }^{*}\right)$ and 
precipitation $(\mathrm{r}=0.53 *)$. On the other side, it was in negative correlation with the hull index $\left(\mathrm{r}=-0.63^{*}\right)$, (Table 5).

Table 5. The correlation coefficient of the examined traits.

\begin{tabular}{|c|c|c|c|c|c|c|c|c|}
\hline Variable & PH & BY & GY & HI & HUI & PC & Precipitation & Temperature \\
\hline Plant height & 1.00 & $0.72 *$ & $0.79 *$ & 0.78 * & $-0.48^{*}$ & $0.39^{\mathrm{ns}}$ & $0.43^{\mathrm{ns}}$ & $-0.40^{\mathrm{ns}}$ \\
\hline $\begin{array}{l}\text { Biomass } \\
\text { yield }\end{array}$ & & 1.00 & $0.92 * *$ & $0.82 *$ & -0.60 * & 0.69 * & 0.53 * & $-0.19^{\mathrm{ns}}$ \\
\hline Grain yield & & & 1.00 & $0.98^{* *}$ & $-0.61^{*}$ & $0.46^{*}$ & $0.70 *$ & $-0.21^{\mathrm{ns}}$ \\
\hline $\begin{array}{l}\text { Harvest } \\
\text { index }\end{array}$ & & & & 1.00 & -0.56 & $0.30^{\mathrm{ns}}$ & $0.73 *$ & $-0.23^{\mathrm{ns}}$ \\
\hline Hull index & & & & & 1.00 & $-0.15^{\mathrm{ns}}$ & $-0.67 *$ & $-0.31^{\mathrm{ns}}$ \\
\hline $\begin{array}{l}\text { Protein } \\
\text { content }\end{array}$ & & & & & & 1.00 & $-0.13^{\mathrm{ns}}$ & $-0.32^{\mathrm{ns}}$ \\
\hline
\end{tabular}

ns_not significant; *significant_level of probability 95\%; **significant-level of probability $99 \%$; PH: plant height; BY: biomass yield; GY: grain yield; HI: harvest index; HUI: hull index; PC: protein content.

The grain yield was in strong positive correlation with the harvest index $\left(\mathrm{r}=0.98^{* *}\right)$, biomass yield $(r=0.92 *)$, and positively correlated with plant height $\left(r=0.79{ }^{*}\right)$ and precipitation $\left(r=0.70^{* *}\right)$. As well as this, above ground biomass and grain yield was negatively correlated with the hull index $(\mathrm{r}=-0.60 *, \mathrm{r}=-0.61 *)$. The protein content was significantly positively correlated with the biomass yield $\left(r=0.69^{*}\right)$ and grain yield $\left(r=0.46^{*}\right)$, and positively non significantly correlated with the plant height $(r=0.39)$ and harvest index $(\mathrm{r}=0.31)$. The protein content was negatively non significantly correlated with the hull index $(\mathrm{r}=-0.15)$, (Table 5).

\section{Discussion}

Oats, among the small grains, are considered as a one of the plant species more tolerant to low soil $\mathrm{pH}$ values and high content of mobile $\mathrm{Al}$ compared to wheat [22]. The analysis of the impact of agroecological conditions on the productivity of black oats should answer the questions of the possibility of their use in the specific agroclimatic conditions of the South Banat region. The presented results showed that significant variation for most of the observed traits was manifested in the experiment due to heterogeneous soil types and weather conditions.

\subsection{Meteorological and Soil Conditions during Vegetation Periods}

In general, most of the examinated traits in this study were significantly higher on chernozem compared to humogley. The average yield and the yield quality of black oat, like other traits, were conditioned by the heterogeneity of soil types and increased with the increase in soil fertility. Furthermore, the meteorological conditions in the investigated period also showed a significant impact on the aboveground plant biomass production and other traits of this variety. Although the black oat is less susceptible to unfavorable agroecological conditions [23], for grain production the crop still needs more favorable conditions for optimal growth. Although the obtained differences were statistically significant, the aboveground biomass of humogley $\left(11.29 \mathrm{t} \mathrm{ha}^{-1}\right)$ indicates that this species can be successfully grown and utilized in production as a cover or fodder crop even in less favorable soil conditions.

Sufficient rainfall during the spring of 2019, which is crucial for successful oat production [22], resulted in a significant increase in the value of all studied productivity parameters compared to the first two years. Significantly lower values of the examined traits in 2017 and 2018 resulted from the outcome of less total precipitation in the spring and its unequal distribution by months, followed by higher average air temperatures. In spring cereal grains, the time of plant germination significantly influences the tillering [1] In the year with the lowest values of productivity parameters (2018), the colder March 
caused the later onset of plant emergence, which, with less water in April and significantly warmer weather in April and May, shortened the vegetation period (Table 2).

The variable climatic conditions also affected the length of the heading growth stage, and if that period lasts longer, there are all the preconditions for the formation of a higher yield of cereal grains [24].

Replacing sensitive genotypes with heat tolerant cultivars and a modification in sowing time are some of the adaptive strategies for the mitigation of yield reduction by climate change [21,24,25].

The results of this study confirm the findings of many authors that the genetically determined productivity of cultivated plants is strongly modified by agroecological conditions [26-30]. When considering the productivity of black oats, in addition to grain yield, as the most important characteristics, and having in mind its use (as a cover or fodder crop), the yield of the aboveground biomass should be especially emphasized.

\subsubsection{Ontogenesis/Individual Development}

Ontogenesis or the development of a plant goes through successive phases that change during its growth. In this investigation, in both types of soil the black oat showed the same growth development, while the shortest vegetation period was observed in the second (2018) growing season. The number of days from sowing to germination was similar in the 2017 and 2019 seasons. During the 2018 season this period was significantly longer in both localities, as a consequence of lower temperatures during March. Later tillering during April in the 2018 season, followed by a sharp rise in air temperature, caused accelerated plant development and plants quickly went into the intensive growth stage and the side shoots remained undeveloped. Oat development depended on local climatic conditions, mainly due to air temperature, which is more effective in the duration of the period from plant emergence to the end of heading. The duration of the fruit development stage, specifically grain filling, is significantly influenced by environmental factors, primarily by high temperatures, which shorten this period [22]. These results are in accordance with previous findings of several authors [31-33]. Gonçalves et al. [31]. describe that the increase in rainfall leads to easier decomposition of the soil cover, bringing benefits in the release of nutrients for their use by plants in succession.

\subsection{Productivity Parameters}

\subsubsection{Plant Height}

The results of this study showed that the plant heights of oats in chernozem soil were higher than plant heights in humogley soil. However, the significantly higher overall mean value for plant height was denoted in the second vegetation season (2019) compared to average values in 2018 and 2017 seasons. This indicates that besides soil influences, the year, along with the weather conditions, significantly affected this trait. This can be expected since the plant height of the oat, as for all cereals, is considered as a quantitative and variable trait whose expression highly depends on environmental factors $[16,34,35]$. According to Molla et al. [36] higher variation in plant height might be attributed to factors such as season and soil type, which can positively affect these characteristics. The variation in plant height may be attributed to variations in genetic make-up, soil type, season and the adaptability of the varieties to different environmental conditions.

\subsubsection{Aboveground Plant Biomass (Biomass Yield)}

Related to the trait of aboveground biomass, the greatest and significantly higher overall mean value was observed in chernozem soil compared with the values on humogley soil. These results are in agreement with results obtained by Jakšić [14]. Since the 2019 season achieved the greatest value of aboveground biomass, it becomes clear that the year had a significant impact on this trait. Although these differences were statistically significant, the black oat biomass yield achieved in humogley $\left(11.29 \mathrm{t} \mathrm{ha}^{-1}\right)$ indicates that this species can be successfully grown as a cover or fodder crop even in less favorable soil 
conditions. Better meteorological conditions in that period also showed a good impact on aboveground plant biomass production. Molla et al. [36] state that the biomass yield and nutritional value were affected by the harvesting stages. The different oat varieties in their study also showed variations in most measured traits due to differences in genetic, seasonal and environmental factors.

Peterson et al. [37] indicate a faster growth of black oats and their biomass has a higher nitrogen concentration and a narrower $\mathrm{C}: \mathrm{N}$ ratio compared to other small grains. The amounts of biomass in this plant species are similar to other small grains (e.g., rye, wheat [2]), which is in accordance with the results of this study.

\subsubsection{Harvest Index}

Regarding the harvest index, the presented results revealed that different soil types influenced the differences in this trait. Significantly higher values of harvest index were achieved in chernozem soil, while lower values were obtained in the humogley type. The harvest index was found to be greater in 2019 season than other seasons, indicating a greater influence of meteorological conditions. The harvest index represents the ratio between the total biological yield and the grain yield. The harvest index is generally under higher environmental impact and greater in favorable growth conditions $[33,38]$. Peltonen-Sainio and Hakala [38] reported that a low or high harvest index can be the result of favorable or unfavorable growth conditions, and that depends on the time of the occurrence and duration of such periods. Ma et al. [39] suggest that enhancing the harvest index and resistance to crop lodging are the primary targets for both the hulled and hulless oat cultivar improvement in eastern Canada.

\subsubsection{Grain Yield}

With regard to the grain yield, the greatest values were observed on chernozem soil. Aditionally at the 2019 season the grain yield was significantly higher compared to 2018 and 2017 seasons. These results indicated that aside from soil type, better meteorological conditions in the 2019 season also had a significant impact on grain yield production. The highest values of the studied traits were achieved in chernozem soil. These results are in agreement with the results obtained by Jakšić [14] who observed that the average yield and the quality of the fodder increased with increasing soil fertility, while the highest yields were achieved in chernozem. Grain yield is a complex property that has a polygenic inheritance. It is the result of the interactions between the variety, the applied agrotechnics and the growth conditions throughout the entire life cycle [1].

\subsubsection{Hull Index}

The average value of this parameter was also higher in the chernozem soil type compared to humogley and this variation was statistically significant. The year also had an impact and the largest values were observed in 2017. In the conditions of more favorable water and heat, spelt plants (Triticum spelta L.) have a lower weed index than during dry years [17], which is in accordance with the results of our research on black oats.

\subsubsection{Protein Content}

The results of the experiment show that the influence of soil type on protein content in oat grain was also significant. The highest average content was found in the tested oat plants originating from chernozem and the lowest in the grains of plants from humogley. The protein content in the 2017 season was significantly higher compared to the 2018 and 2019 seasons. The protein content in the grain is one of the most important parameters of oat quality [1]. The authors point out that the protein content in grains is highly modified by environmental conditions and applied agrotechnical measures. The mean crude protein content was significantly $(p<0.001)$ affected by the harvesting stages and the interaction effects $(p<0.05)$ [36]. Mut [40] also states that genetic characteristics are the basis for 
variation in the nutritive values that determine production, utilization and the various management practices.

The organic farming system has been adapted for many climate zones and local conditions [37]. Agronomic performance and quality traits are affected by environmental conditions and growing season [41-44]. However, nitrogen $(\mathrm{N})$ fertilization management and the irregular availability of $\mathrm{N}$ due to factors influencing mineralization in the soil are two of the biggest challenges for organic farming [42,43]. Farmers view low yields and limited access to fertilizers and seeds as the two top-ranked obstacles; this is largely the reason for low levels of supply. Low yields and production volumes are the reason why many farmers see organic farming as being risky. The case study of Poland, which is among the emerging markets for organic food, shows that a stable and coherent support policy is a condition for organic-farming development [45]. In the Republic of Serbia, especially in its central part, the production of cereals is mainly carried out on soils with acidic and extremely acidic reactions, very low quality structures that are poor in organic matter. In acidic soils, a universal fertilization system does not exist due to the very uneven physical and chemical properties of these soils. Therefore, the application of fertilizers to acid soils must be approached in a much more rational and multi-faceted manner [46,47]. This study provided a better understanding about the effect of locality growing on yield and some quality traits of black oats in organic farming.

To maintain the sustainability of oat production in Serbia, it is necessary to reexamine many of the existing approaches to alleviate climatic change-induced problems in oat cultivation in the oat growing area of agroecological conditions in Pannonian environments, and develop a set of best management practices.

\section{Conclusions}

The study of the influence of soil type and meteorological factors on the ontogenesis of black oats indicates a pattern similar to other small grains in the agroecological conditions of South Banat. Significant variation in observed traits was shown in the experiment due to heterogeneous weather and soil conditions. The above-ground biomass yield, grain yield and grain protein content were higher in chernozem compared to humogley soil. Observed by years, all productivity parameters differed significantly, which confirmed that the genetically determined productivity of cultivated plants was strongly modified by agroecological conditions. Although these differences were statistically significant, the black oat biomass yield achieved in humogley $\left(11.29 \mathrm{t} \mathrm{ha}^{-1}\right)$ indicates that this species can be successfully grown as a cover or fodder crop even in less favorable soil conditions. The results of this investigation could have scientific, but also practical significance in the establishment and exploitation of areas under cover or fodder crops, as well as in environmental protection.

Author Contributions: The contributions of each author are as follows: Conceptualization, V.U. and V.P.; methodology, V.U.; software, V.F.; validation N.L., formal analysis, V.P., K.M., Ž.L. and S.P.; investigation, V.U. and V.F.; resources, V.U.; data curation, M.U.; writing—original draft preparation, V.U., V.P., Ž.L. and K.M.; writing_-review and editing, V.F.; visualization, N.L.; project administration, V.P. and V.U.; supervision, M.U. All authors have read and agreed to the published version of the manuscript.

Funding: This research received no external funding.

Data Availability Statement: The data presented in this study are available within the article.

Acknowledgments: Research was supported by the Ministry of Education, Science and Technological Development of the Republic of Serbia (Grant numbers: 451-03-68/2020-14/200011; 200032; 200216; 200358 and 200003); and FAO project 2020-2022: Redesigning the exploitation of small grains genetic resources towards increased sustainability of grain-value chain and improved farmers' livelihoods in Serbia and Bulgaria (GRAINeFIT).

Conflicts of Interest: The authors declare no conflict of interest. 


\section{References}

1. Glamočlija, Đ.; Janković, S.; Popović, V.; Kuzevski, J.; Filipović, V.; Ugrenović, V. Alternatively Crop Plants in Conventional and Organic Growing Systems; Monography; Institute for Science Application in Agriculture: Belgrade, Serbia, 2015; pp. 1-355. ISBN 978-86-81689-32-5.

2. Dial, H.L. Plant Guide for Black Oat (Avena strigosa Schreb.) USDA-Natural Resources Conservation Service; Tucson Plant Materials Center: Tucson, AZ, USA, 2014; p. 85705.

3. Ashford, D.L.; Reeves, D.W. Use of a mechanical roller-crimper as an alternative kill method for cover crops. Am. J. Altern. Agric. 2003, 18, 37-45. [CrossRef]

4. Andognini, J.; Albuquerque, J.A.; Warmling, M.I.; Teles, J.S.; Silva, G.B. Soil compaction effect on black oat yield in Santa Catarina, Brazil. Rev. Bras. Ciência Solo 2020, 44, e0190157. [CrossRef]

5. Vicensi, M.; Lopes, C.; Koszalka, V.; Umburanas, R.C.; Borecki Vidigal, J.C.; de Ávila, F.W.; Lopes Müller, M.M. Soil Fertility, Root and Aboveground Growth of Black Oat Under Gypsum and Urea Rates in No Till. J. Soil Sci. Plant Nutr. 2020, 20, 1271-1286. [CrossRef]

6. Frey, L. Distribution of Avena strigosa (Poaceae) in Europe. Fragm. Florist. Geobot. 1991, 36, 281-288.

7. Weibul, J.; Bojesen, L.L.J.; Rasomavièvius, V. Avena strigosa in Denmark and Lithuania: Prospects for in situ conservation. Plant Genet. Resour. Newsl. 2002, 131, 1-6.

8. Scholten, M.; Spoor, B.; Green, N. Machair corn: Management and conservation of a historical machair component. Glasg. Nat. 2009, 25, 63-71.

9. Restelatto, R.; Pavinato, P.S.; Sartor, L.R.; Paixão, S.J. Production and nutritional value of sorghum and black oat forages under nitrogen fertilization. Grass Forage Sci. 2013, 69, 693-704. [CrossRef]

10. Ugrenović, V. Organic Production of Grain; National Association for Organic Production Serbia Organica: Belgrade, Serbia, 2018; pp. 1-63.

11. Ikanović, J.; Popović, V. Organic Plant Production; National Association Serbia Organica: Belgrade, Serbia, $2017 ;$ pp. 1-233.

12. Ugrenović, V.; Bodroža Solarov, M.; Filipović, V.; Međeeši, B.; Ugrinović, M. Black Oat (Avena strigosa Schreb) - New Species in Production in Serbia. In Proceedings of the 3rd International Conference Agrobiodiversity Organic Agriculture for Agrobiodiversity Preservation, Novi Sad, Serbia, 1-3 June 2017; p. 63.

13. Dimitrijević, M.; Petrović, S.; Belić, M.; Banjac, B.; Vukosavljev, M.; Mladenov, N.; Hristov, N. The Influence of Solonetz Soil Limited Growth Conditions on Bread Wheat Yield. J. Agric. Sci. Technol. 2011, 5, 194-201.

14. Jakšić, S. Effect of forage crops, soil type and soil fertility on productivity and and chemical composition of roughage. Ph.D. Thesis, University of Belgrade, Faculty of Agriculture, Belgrade, Serbia, 2014; pp. 1-212.

15. Hack, H.; Gall, H.; Klemke, T.; Klose, R.; Meier, U.; Stauss, R.; Witzenberger, A. The BBCH scale for phonological growth stages. In U. Meier (Ed.), Growth Stages of Mono- and Dicotyledonous Plants. Bbch Monograph. Ger. 2001, 1-158.

16. Ugrenović, V.; Bodroža Solarov, M.; Pezo, L.; Đisalov, J.; Popović, V.; Marić, B.; Filipović, V. Analysis of spelt variability (Triticum spelta L.) grown in different conditions of Serbia by organic conditions. Genetics 2018, 50, 635-646.

17. Ugrenović, V.; Filipović, V.; Popović, V.; Glamočlija, Đ. Hull Index - Indicator of Hulled Wheat Productivity and Quality. Plant. Breed. Seed Prod. 2015, 21, 31-38.

18. Jones, D.B. Factors for Converting Percentages of Nitrogen in Foods and Feeds into Percentages of Protein; US Department of Agriculture: Washington, DC, USA, 1941; pp. 1-183.

19. Živković, B.; Nejgebauer, V.; Tanasijević, Đ.; Miljković, N.; Stojković, L.; Drezgić, P. Soils of Vojvodina. Book N. S. Serb. 1972, 380-403.

20. Belić, M.; Nešić, L.; Ćirić, V.; Vasin, J.; Milošev, V.; Šeremešić, S. Characteristics and Classification of Gleyic Soils of Banat. Ratar. Povrt. Field Veg. Crop. 2011, 48, 375-382. [CrossRef]

21. Jelić, M.; Dugalić, G.; Milivojević, J.; Đekić, V. Effect of liming and fertilization on yield and quality of oat (Avena sativa L.) on an acid luvisol soil. Rom. Agric. Res. 2013, 30, 249-258.

22. Rajičić, V.; Popović, V.; Perišić, V.; Biberdžić, M.; Jovović, Z.; Gudžić, N.; Mihailović, V.; Čolić, V.; Đurić, N.; Terzić, D. Impact of Nitrogen and Phosphorus on Grain Yield in Winter Triticale Grown on Degraded Vertisol. Agronomy 2020, 10, 757. [CrossRef]

23. Güngör, H.; Dokuyucu, T.; Dumlupinar, Z.; Akkaya, A. Yulafta (Avena spp.) Tane Verimi ile Bazı Tarımsal Özellikler Arasındaki İlişkilerin Korelasyon ve Path Analizleriyle Saptanması. Tekirdă̆ Ziraat Fakültesi Derg. 2017, 14, 61-68.

24. Raza, A.; Razzaq, A.; Mehmood, S.S.; Zou, X.; Zhang, X.; Lv, Y.; Xu, J. Impact of Climate Change on Crops Adaptation and Strategies to Tackle Its Outcome: A Review. Plants 2019, 8, 34. [CrossRef]

25. Khan, S.; Anwar, S.; Ashraf, M.Y.; Khaliq, B.; Sun, M.; Hussain, S.; Gao, Z.-Q.; Noor, H.; Alam, S. Mechanisms and Adaptation Strategies to Improve Heat Tolerance in Rice. A Review. Plants 2019, 8, 508. [CrossRef]

26. Kubiak, K. Genetic diversity of Avena strigosa Schreb. ecotypes on the basis of isoenzyme markers. Biodivers. Res. Conserv. 2009, 15, 23-28. [CrossRef]

27. Doehlert, D.C.; McMullen, M.S.; Hammond, J.J. Genotypic and environmental effects on grain yield and quality of oat grown in North Dakota. Crop. Sci. 2001, 41, 1066-1072. [CrossRef]

28. Peterson, D.M.; Westenberg, D.M.; Burrup, D.E.; Erickson, C.A. Relationships among agronomic traits and grain composition in oat genotypes grown in different environments. Crop. Sci. 2005, 45, 1249-1255. [CrossRef]

29. Calzarano, F.; Stagnari, F.; D’Egidio, S.; Pagnani, G.; Galieni, A.; Di Marco, S.; Metruccio, E.G.; Pisante, M. Durum Wheat Quality, Yield and Sanitary Status under Conservation Agriculture. Agriculture 2018, 8, 140. [CrossRef] 
30. Đekić, V.; Jelić, M.; Popović, V.; Terzić, D.; Đurić, N.; Grčak, D.; Grčak, M. Parameters of grain yield and quality of spring oats. Proc. J. Pkb Agroekonomik Inst. 2018, 24, 81-86.

31. Gonçalves, S.L.; Saraiva, O.F.; Torres, E. Influência de fatores climáticos na decomposição de resíduos culturais de aveia e trigo. Bookempresa Bras. Pesqui. Agropecuária Embrapa Soja 2010, 1-27.

32. Mantai, R.D.; Silva, J.A.G.; da Marolli, A.; Mamann, Â.T.W.; de Sawicki, S.; Cleusa, A.M.B.K. Simulation of oat development cycle by photoperiod and temperature. Rev. Bras. Eng. Agrícola Ambient. 2017, 21, 3-8. [CrossRef]

33. Ugrenović, V. Impact of Seeding Date and Crop Density on the Ontogenesis, Yield and Quality of Spelt Grain (Triticum spelta L.). Ph.D. Thesis, Faculty of Agriculture, University of Belgrade, Belgrade, Serbia, 2013; pp. 1-135.

34. Zečević, V.; Knežević, D.; Mićanović, D.; Pavlović, M.; Urošević, D. The inheritance of plant height in winter wheat. Genetika 2005, 37, 173-179.

35. Popović, V.; Ljubičić, N.; Kostić, M.; Radulović, M.; Blagojević, D.; Ugrenović, V.; Popović, D.; Ivošević, B. Genotype $\times$ Environment Interaction for Wheat Yield Traits Suitable for Selection in Different Seed Priming Conditions. Plants 2020, 9, 1804. [CrossRef]

36. Molla, E.A.; Wondimagegn, B.A.; Chekol, Y.M. Evaluation of biomass yield and nutritional quality of oats-vetch mixtures at different harvesting stage under residual moisture in Fogera District, Ethiopia. Agric. Food Secur. 2018, 7, 88. [CrossRef]

37. Patterson, M.J.; Reeves, D.W.; Gamble, B.E. Weed Management with Black Oat (Avena strigosa) in No-Till Cotton. In Proceedings Beltwide Cotton Conferences, Nashville, TN, USA, 9-12 January 2003; National Cotton Council: Memphis, TN, USA, 1996; Volume 2, pp. 1557-1558.

38. Peltonen-Sainio, P.; Muurinen, S.; Rajala, A.; Jauhiainen, L. Variation in harvest index of modern spring barley, oat and wheat cultivars adapted to northern growing conditions. J. Agric. Sci. 2008, 146, 35-47. [CrossRef]

39. Ma, B.L.; Kumar Biswas, D.; Zhou, Q.P.; Ren, C.Z. Comparisons among cultivars of wheat, hulled and hulless oats: Effects of N fertilization on growth and yield. Can. J. Plant. Sci. 2012, 92, 1213-1222. [CrossRef]

40. Mut, Z.; Akay, H.; Köse, O. Grain yield, quality traits and grain yield stability of local oat cultivars. J. Soil Sci. Plant. Nutr. 2018, 18, 269-281.

41. Sembiring, H.A.; Subekti, N.; Erythrina Nugraha, D.; Priatmojo, B.; Stuart, A.M. Yield Gap Management under Seawater Intrusion Areas of Indonesia to Improve Rice Productivity and Resilience to Climate Change. Agriculture. 2020, 10, 1. [CrossRef]

42. Pandino, G.; Mattiolo, E.; Lombardo, S.; Lombardo, G.M.; Mauromicale, G. Organic Cropping System Affects Grain Chemical Composition, Rheological and Agronomic Performance of Durum Wheat. Agriculture. 2020, 10, 46. [CrossRef]

43. Osman, A.M.; Struik, P.C.; Lammerts van Bueren, E.T. Perspectives to breed for improved baking quality wheat varieties adapted to organic growing conditions. J. Sci. Food Agric. 2011, 92, 207-215. [CrossRef] [PubMed]

44. Keres, I.; Alaru, M.; Talgre, L.; Luik, A.; Eremeev, V.; Sats, A.; Jõudu, I.; Riisalu, A.; Loit, E. Impact of Weather Conditions and Farming Systems on Size Distribution of Starch Granules and Flour Yield of Winter Wheat. Agriculture 2020, 10, 22. [CrossRef]

45. Łuczka, W.; Kalinowski, S. Barriers to the Development of Organic Farming: A Polish Case Study. Agriculture 2020, $10,536$. [CrossRef]

46. Rajičić, V.; Popović, V.; Terzić, D.; Grčak, D.; Dugalić, M.; Mihailović, A.; Grčak, M.; Ugrenović, V. Impact of lime and NPK fertilizers on yield and quality of oats on pseudogley soil and their valorisation. Not. Bot. Horti Agrobot. Cluj-Napoca 2020, 48, $2134-2152$. [CrossRef]

47. Souissi, A.; Bahri, H.; Cheikh M'hamed, H.; Chakroun, M.; Benyoussef, S.; Frija, A.; Annabi, M. Effect of Tillage, Previous Crop, and N Fertilization on Agronomic and Economic Performances of Durum Wheat (Triticum durum Desf.) under Rainfed Semi-Arid Environment. Agronomy 2020, 10, 1161. [CrossRef] 